\title{
НЕПОПРАВНІ ВТРАТИ
}
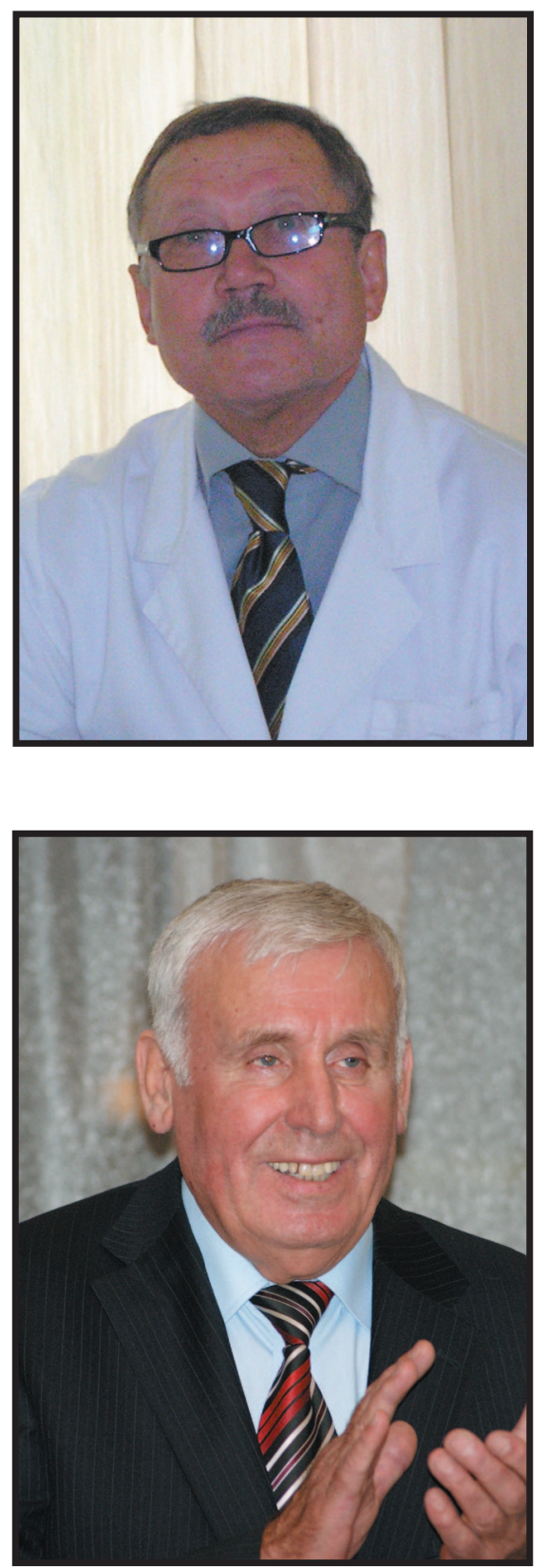

\subsubsection{4 року не стало МИКОЛИ ВАСИЛЬОВИЧА БУЛАХА}

М.В. Булах народився 11.10.1951 р. у с. Слобідка Чернігівської області. Закінчивши Обухівське медичне училище, працював фельдшером в Обухівській санепідстанції. 1976 року закінчив Київський медичний інститут. 31976 по 1993 роки працював лікарем-анестезіологом у Київському НДІ клінічної та експериментальної хірургії (нині - Національний інститут хірургії та трансплантології ім. О.О. Шалімова). 1993-1997 роками працював анестезіологом у Лівійській Джамахірії. 31997 року до останнього дня свого життя працював в Українському науковопрактичному центрі ендокринної хірургії, трансплантації ендокринних органів і тканин МОЗ України. Він був серед тих, хто розпочинав створювати реанімаційну службу Центру та впродовж 11 років керував нею, рятуючи життя тисячам пацієнтів.

\subsubsection{4 року не стало \\ Заслуженого лікаря України, кандидата медичних наук}

\section{АНАТОЛІЯ ІВАНОВИЧА ШЕПТУХИ}

A.I. Шептуха народився 28.12.1939 р. у с. Новомихайлівка Маріїнського р-ну Донецької області. Після закінчення середньої школи відслужив 2 роки у Радянській армії, поступив до Київського медичного інституту, якій закінчив 1967 року. По закінченні інтернатури з 1969 по 1994 роки працював лікаремхірургом у Київському НДІ ендокринології та обміну речовин (нині - ДУ «Інститут ендокринології та обміну речовин ім. В.П. Комісаренка НАМН України»). 1974-1976 роками надавав медичну допомогу населенню Афганістану. Крім лікувальної роботи, Анатолій Іванович займався й науковою діяльністю, 1980 року захистив кандидатську дисертацію. 3 моменту заснування 1994 року до кінця 2005 року завідував хірургічним відділенням Українського науково-практичного центру ендокринної хірургії, трансплантації ендокринних органів і тканин MO3 України, з 2006 року працював лікарем-хірургом у КМКЛ № 3. Ім'я A.І. Шептухи як одного з перших і найліпших ендокринних хірургів, як лікаря милістю Божою відоме в усій країні та за їі межами, йому вдячні тисячі людей, яким він повернув здоров'я.

Пішли 3 життя фахівці найвищого ґатунку, люди надзвичайно щирої, веселої вдачі, надійні та вірні товариші.

Ми висловлюємо щирі співчуття рідним і близьким Миколи Васильовича та Анатолія Івановича й сумуємо разом із ними.

Вічна світла пам'ять! 